\title{
Research on the Systematization of Financial Management in Colleges Guanzhuo Wang ${ }^{1,}$, Daxu Liu ${ }^{1, b}$, Yang Mu ${ }^{1, c}$, Hong Wu ${ }^{1, d}$ \\ ${ }^{1}$ Heilongjiang University of Chinese Medicine, Jiamusi, Heilongjiang, 154002 \\ a email, ${ }^{\text {b email, }}{ }^{\mathrm{c}}$ email, ${ }^{\mathrm{d}}$ email
}

Keywords: Financial Management, Systematization, Colleges

\begin{abstract}
Colleges and universities in the process of expanding the scale of running schools to improve the level of the process, the financial management system cannot meet the requirements of higher education development and do need to establish a set of dynamic operating mechanism. This paper explores the optimization of financial management system in colleges and universities through empirical research and quantitative analysis.
\end{abstract}

\section{Introduction}

Looking forward to the 21st century, university financial management still faces many new reform tasks. Generally speaking, at present, the financial management of colleges and universities is still in the transition from the financial management mode of the planned economy to the market economy system, and there are many traces of the management mode and mode of the planned system, and the rapid development of the university diversified management system. Adaptation. Schools must be socially autonomous, in the competition in the market economy to survive and develop. Once the school really enters the market, seeking survival and development in the market, it will greatly enhance the school's own reform and development of the driving force and vitality, but at the same time the school also faces some new problems, such as: how to deal with the development and stability, long-term interests and the relationship between immediate interests. With the school within the various types of industries more and more, this diversification of the main interests of the formation of the school's financial management work also produced a corresponding financial risk. In this situation, the financial management work should be transferred to improve efficiency as the goal, and actively rationalize the various economic relations within the school, increase financial reform and management efforts to regulate the school's economic activities, strengthen the basic accounting work, control financial risks, So that financial management gradually from the accounting type to the management and business-oriented change, and its gradual institutionalization, standardization and scientific. Therefore, it is a very important work in the reform of colleges and universities, which is related to the development and future fate of the university economy. This is the specific purpose of this paper.

\section{The Current Situation of Financial Management System in Chinese Universities}

At present, China's colleges and universities in the financial organization structure is basically a straight line function system, by the school's primary financial institutions, namely the Finance Department (or Finance Department) unified management of the school's financial work, but because of the financial functions Understanding of the differences and the specific circumstances of the school, in the financial department of subordinate institutions set up, there are large differences in colleges and universities, in addition to the basic financial institutions that accounting and cashier Division the same, the other departments can be described as a wide variety of settings, If the school set up the Budget Management Section, Financial Management Section, Integrated Management Section and other departments, some schools have additional audit room, infrastructure finance, state-owned assets management, personnel and other departments, and some schools also set up a major Project funds management and foreign capital utilization, etc., these departments are necessary, such as the Financial Management Section, the State-owned Assets Management Section, the other basically belong to the institutional re-set, is not conducive to the 
unified and standardized financial management, but also a Human and financial resources, their functions should be included in the financial management section.

In order to mobilize the enthusiasm of the two units and to reduce the intensity of the work of the functional departments to consider, many colleges and universities have set up a secondary financial accounting institutions, but it also brings the school level of financial management of the weak financial weaknesses, which Because the secondary financial accounting institutions are divided by different leaders, each department self-contained, fragmented, resulting in unreasonable division of school financial management, a financial management institutions is difficult to the two financial institutions of the economic business Unified management and leadership. Therefore, it is necessary to minimize the setting of the secondary financial institutions and to restrict and manage the strict internal financial control system for the secondary financial institutions that have to be set up.

China's universities and resources related to the financial, personnel, infrastructure, assets, equipment, books and other six aspects of business, respectively, six departmental management, information processing systems are independent operation, the financial sector only bear budget control, accounting, cash Small financial function. This system is related to the institutional setting of government education authorities. From the Ministry of Education to the provinces and municipalities in charge of education departments, set up the functions of the Division, are equipped with these six aspects of the functional departments and personnel. The six departments involved in resource management in colleges and universities must submit data to the higher authorities respectively, and establish their own information processing systems according to the requirements of the regulations. This situation, there are overlapping management agencies, resource management, scattered, both waste of manpower, it is difficult to co-ordinate the use of resources, contrary to the principles of modern management.

At present, most colleges and universities do not establish a cost accounting mechanism. Under the condition of market economy, the financing channels of colleges and universities are greatly widened, and various business activities are becoming more and more frequent. Cost accounting is the necessary content of financial accounting. At the same time, an important problem with the continuous growth of higher education is that the state has the ability of education Which is the common problem encountered in the development of higher education in the world. It is the basis of scientific and reasonable cost accounting because of the financial crisis of higher education, which makes it take the road of cost sharing and compensation. University of financial information feedback channels is not smooth. Most colleges and universities do not establish an effective financial information feedback mechanism. The contents of financial statements and financial analysis cannot provide reference for the development plan of colleges and universities, so that the function of financial forecasting and decision-making does not play. This is due to the neglect of the decision-making bodies and decision-makers in colleges and universities, and on the other hand, because of the reference value of financial information, that is, the information provider does not provide valuable information.

\section{Optimization of Financial Management System in Colleges and Universities}

Financial management of colleges and universities is part of the school management, is related to the acquisition and effective use of funds management. The objectives of financial management should be consistent with the overall development goals of the school to ensure the realization of the overall objectives of the school. Colleges and universities are the center of scientific research and the cradle of cultivating talents. The aim of the university is to put more and better talents for the society to provide more scientific research results with lower manpower, financial and material resources. Therefore, the goal of university financial management should be consistent with the goal of running a university, directly reflecting the basic characteristics of financial management. To ensure the normalization of university financial situation is the basic goal of university financial management. University is a legal entity for the society to run autonomously. In order to fulfill the duties of teaching and educating people, the completion of education must serve the task of socialist modernization, colleges and universities must have a stable source of funding, these sources of 
funding channels are: financial allocation as the main channel, education fees, school industry, social donations As an auxiliary channel. In addition, there are various borrowing and payable and temporary payments in the course of economic transactions. These funds are used in all aspects: the construction of education work to be used in the housing, buildings, equipment, books, storage work required for the use of special materials, low-value consumables, textbooks, stationery office supplies, Economic transactions in the process of various borrowing, receivables and temporary payments and reserves to maintain the daily teaching activities of the monetary funds and securities. Therefore, the financial management of colleges and universities must strive to maintain the ability to offset and repay the debts due, so that it can survive long-term, stable. To survive in the development, and constantly expand the income to raise funds needed for the development of colleges and universities through reasonable and effective use of funds to solve the growing needs of education institutions in colleges and universities more demand for education and slow growth of education funding for education The lack of supply between the contradictions, to maintain the best cash flow, to ensure the normalization of the financial status of the basic objectives.

Budget management in colleges and universities is an important part of financial management in colleges and universities. It runs through the whole process of financial management in colleges and universities, and it is the prerequisite and basis for the financial activities of colleges and universities. Since the founding of the PRC, the budget of the university has gone through three stages. The first stage is the product of the planned economy. After the founding of the People's Republic of China in the past three decades, all the education funds have been contracted down by the state. The budget is only the income and expenditure of the single financial appropriation. Although this stage of the budget preparation is flawed, the control of education funding has played a role. The second stage, that is, the transition from a single financial allocation budget to the consolidated financial budget. After the Third Plenary Session of the 11th CPC Central Committee, the colleges and universities have a certain degree of autonomy, income to diversified development, the relative increase in school financial resources, schools in order to strengthen the budget, the management of foreign funds, the preparation of all available income School budget. The third stage, for the implementation of the integrated financial budget implementation stage, to determine the centralized and unified, large income budget principle, standardize the operation of the university financial budget, the university integrated financial budget is gradually improving, for the university financial budget Opened up a new course. However, the current colleges and universities in the budget preparation and implementation process, there are still unsatisfactory.

The essence of budget management is the rational allocation of scarce resources, due to the limited resources, people must budget, so that the organization's resources to be the most effective use. It can be seen that the budget itself means a balance, and a financial plan that does not take into account the income to make up for it cannot be called a budget. Therefore, the primary principle of budgeting in colleges and universities is the balance of payments, not the principle of deficit 0 . The overall budget management we propose is that the budgets at all levels of the school include the income budget and the expenditure budget so that the expenditure of each department is controlled within the range of income that may be available in the sector, making the balance of the total budget The relationship is based on the balance of revenue and expenditure of various departments to improve the effectiveness of budget control.

The rights and responsibilities are divided according to the division of functions and functions of various departments, and are reflected in the form of economic responsibility. At the same time, the performance evaluation of the economic responsibility is evaluated through the performance appraisal. However, the exercise of the right to exercise and the responsibility of economic responsibility must be provided with financial protection in order to effectively ensure that the budget units in strict accordance with the budget to complete the intended target, perform their duties. Power is the essence of financial power is to protect, give financial power to make the right to be implemented. Financial rights concentrated in the income and expenditure rights in two aspects, the responsibility of the departments to perform their duties will inevitably occur, that is, through the exercise of the exercise of power. Therefore, to assess their performance must make the 
perpetrators through the exercise of the exercise of the right to adjust their behavior in order to achieve the budget objectives. Otherwise out of the right to financial power is an empty right, the performance of duties is a passive behavior.

The budget itself means a break-even, so the basic goal of budget management is to balance payments and break-even. Once the budget is approved to enter the budget execution process, the implementation of the budget process is the budget control process, so the budget implementation depends directly on the budget control effect. In any budget approved by the prescribed procedure, no part of any person may change, and if the circumstances change really needs to change the budget, the budget must be adjusted in accordance with the prescribed procedures to ensure the scientific and seriousness of the budget. Strictly speaking, the acquisition of budgetary revenues, the use of budgetary funds, the adjustment and change of budgets, and the analysis, assessment and evaluation of budget performance are all within the scope of budget implementation. University budget through institutionalized, standardized management, strengthen the rigid and binding budget, in order to ensure the overall balance of the budget.

\section{Conclusion}

University financial management system from its scope, content and management level, nothing more than two core systems, namely, financial management organization system and financial management index system. Financial management organization system and financial management index system are interrelated and interactive, the organization system determines the formation and development of the index system, and the scientific and rationality of the index system promotes the reform and development of the organizational system.

\section{Acknowledgements}

Sichuan Hospital Management and Development Research Center, medical union under the background of the reform of the remuneration system, the project number: SCYG2017-28

\section{References}

[1] He Wenbiao. From the institutions to non-profit organizations - China's university financial accounting reform [J]. Journal of Southwest Jiaotong University, 2005 (03)

[2] Chen Qiaoling. Analysis of the use of contingency theory in the management of colleges and universities [J]. Journal of Qiqihar University, 2004 (04)

[3] Jia Yanmei. Establishment of financial management system for the two levels of management, school. [J]. Jiangsu Higher Education, 2003 (04)

[4] Chen Xiaofang.Study on the financial management of colleges and universities [J]. Journal of Hunan Urban Construction College, 2003 (02)

[5] He Wenbiao. University financial management system reform [J]. Business Accounting, 2003 (01)

[6] Chen Yiping. Study on the Financial Management System of University Based on Business Process [J] .Community Accounting, 2002 (06) 